\title{
Effects of mercury on physiological condition and content of the biomarker ALA in the oyster Ostrea edulis
}

\author{
Vibeke Brock \\ Biology Institute, University of Odense, Campusvej 55, DK-5230 Odense M, Denmark
}

\begin{abstract}
Ostrea edulis (L.) exposed to mercury in situ at Cheminova in the western part of Nissum Bredning, Limfjord, Denmark, was compared to a non-exposed oyster sample from the uncontaminated eastern part of the area. A similar comparison was made for oysters, exposed and non-exposed to $\mathrm{Hg}$, in the laboratory. Comparisons were based on stepwise multiple regression analysis, and MANOVA, using these variables: shell length, volume between shell valves, tissue dry weight, length and width of shell muscle scar, and infection by the parasite Bonamia ostreae (determined by ELISA). For the environmental as well as for the laboratory samples, no significant differences between exposed and non-exposed oysters were found. The content of the biomarker $\delta$-aminolevulinic acid (ALA) was detected by ion-exchange chromatography in all samples. ALA content (related to amount of soluble protein) was significantly elevated in mercury-exposed oysters, in both the field and the laboratory. Similar differences were observed for environmental samples of cockles Cerastoderma edule (L.), mussels Mytilus edulis (L.) and periwinkles Littorina littorea (L.) from the Cheminova site and from uncontaminated samples. Possible cause-effect of the mercury-related increase of ALA in molluscs is discussed.
\end{abstract}

\section{INTRODUCTION}

To establish the hazard of a toxic metal (and other toxic substances) the classical approach is to determine its concentration in the environment and then compare that with concentrations that kill experimental animals under laboratory conditions. A contemporary ecotoxicological approach is necessary when studying sublethal effects of toxins. Preferably, methods should be chosen which correlate tissue concentrations of the toxic substance with a biomarker, e.g. physiological or biochemical changes in the animal studied, and subsequently establish causal relationships between exposure and the observed change [the term 'biomarker' is used in accordance with the following definition: biochemical compounds, processes, structures, or functions, that change due to the exposure of organisms to xenobiotics (National Research Council 1987)].

Healthy-appearing flat oysters with high mercury content were studied in accordance with the first step of the procedure outlined above. The European oyster
Ostrea edulis (L.) has inhabited Danish estuarine and coastal areas for about 8000 yr (E. Bondesen, Roskilde University Center, pers. comm.) and their shells dominate the large vestiges of early Mesolithic man termed 'Køkkenmøddinger' (kitchen middens). In the last century there were still rich oyster beds in the Limfjord (Collin 1872), hence the low abundance today cannot be ascribed to climatic changes. The oyster fishery has decreased during this century, and cultivation of the 'Limfjord oyster' (lately based on imported transplants) was abandoned in the 1980s.

It has not yet been established whether the present oyster scarcity is due to overfishing, anoxic conditions due to pollution with inorganic nutrients, anthropogenic release of toxins, or specific infections e.g. by the intracellular protozoan parasite Bonamia ostreae (Pichot et al. 1980) which has damaged cultures dramatically elsewhere. A study of the genetic variation in Scandinavian oysters (unfortunately not including the Limfjord oysters) shows that they are less variable than other European populations (Johannesson et al. 1989). This 
could be the result of immigration of genetically homogeneous cultured stocks, or it could reflect selection for resistance to a parasite such as $B$. ostreae (EIston et al. 1987).

In the western part of the previously oyster-rich Nissum Bredning (see Fig. 1), there were substantial mercury discharges in the 1950s and 1960 s by the pesticide-producing factory, Cheminova. In this mercury-contaminated environment, where lead and cadmium levels correspond to those found in other Danish coastal areas (Brock 1992), healthyappearing oysters containing about $2500 \mathrm{ng} \mathrm{Hg} \mathrm{g}^{-1}$ dry wt in the gills were collected for the study (Table 1 ).

Mercury is a non-essential metal that forms (1) toxic organic compounds which readily dissolve in lipids and traverse cell membranes, and (2) highly reactive inorganic salts which bind to thiol groups of proteins and peptides. By binding to enzymes (Thaker \& Haritos 1989), mercury probably affects metabolism and it is therefore expected that mercury-contaminated

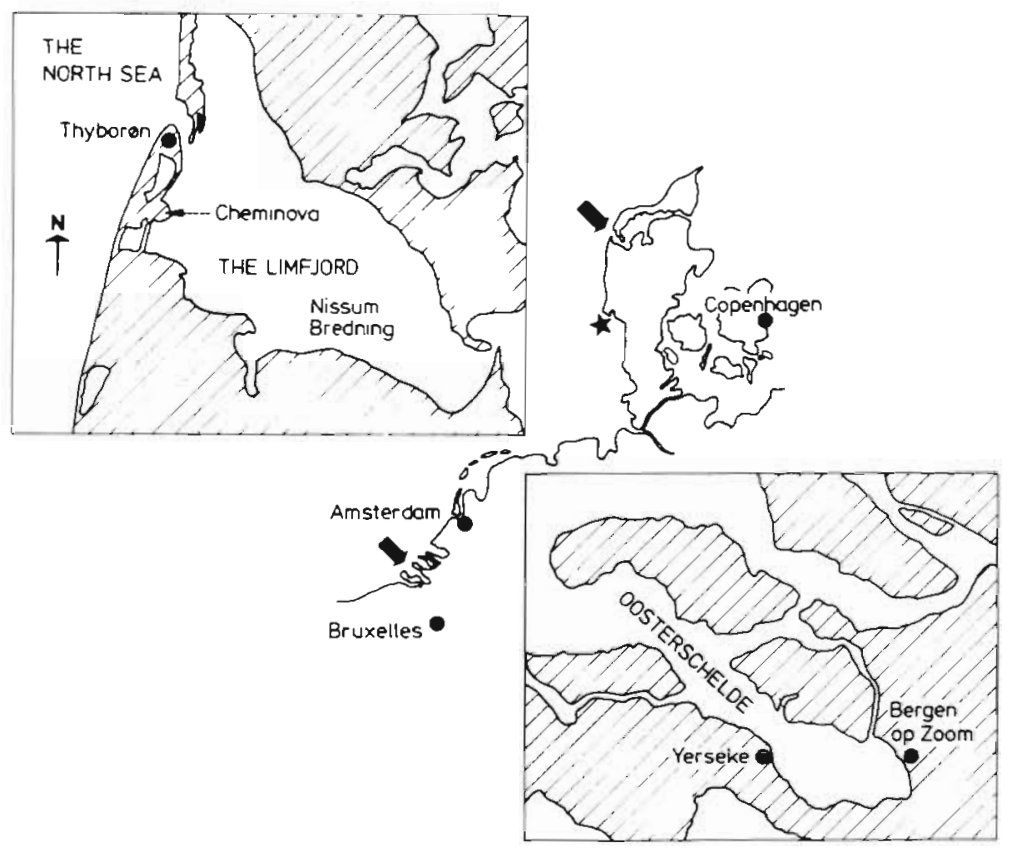

Fig. 1. Mollusc sampling sites in Denmark (upper) and Holland (lower). Ostrea edulis, Littorina littorea, Mytilus edulis and Cerastoderma edule were collected at Cheminova (Denmark), and also at the beach at Yerseke (Holland) except for $C$. edule which was sampled at Skallingen $(\star)$ in the Wadden Sea organisms will exhibit reduced energy balance as compared to non-contaminated organisms. To test whether such a general impact occurs biometrics, including the condition index of in situ as well as of laboratory mercury-exposed oysters, were compared to those of non-exposed reference oysters. Further, to test whether a molecular biomarker might be used to assess non-lethal impacts of mercury, the specific effect of mercury on the porphyrin precursor $\delta$-aminolevulinic acid (ALA) (Brock 1992) was studied in hepatopancreatic tissue of mercury-exposed and non-exposed, environmental and laboratory samples of oysters.

\section{MATERIALS AND METHODS}

Localities and populations. The mercury-contaminated area of the Limfjord south of Tyborøn, Denmark, (Fig. 1) is inhabited by the oyster Ostrea

Table 1. Ostrea edulis. Mean (SD) mercury content of tissues from oysters $(n=29)$ collected at Cheminova, Denmark

\begin{tabular}{|lc|}
\hline Tissue & $\mathrm{Hg}\left(\mathrm{ng} \mathrm{g}^{-1} \mathrm{dry} w \mathrm{wt}\right)$ \\
\hline Gill & $2848(1030)$ \\
Hepatopancreas & $2049(521)$ \\
Muscle & $2154(517)$ \\
Residual & $1866(497)$ \\
\hline
\end{tabular}

edulis ( $\mathrm{L}$ ), the blue mussel Mytilus edulis, the soft clam Mya arenaria (L.), the Baltic clam Macoma balthica $(\mathrm{L}$.$) , the common cockles Cerastoderma edule (L.)$ and C. lamarcki (Reeve), and the periwinkle Littorina littorea (L.). Non-exposed oysters were sampled on 29 October 1990 in the eastern part of the area, where tissue mercury content was less than $100 \mathrm{ng} \mathrm{g}^{-1}$ dry wt (length $=48$ to $75 \mathrm{~mm}, \mathrm{n}=60$ ), and in the mercurycontaminated Cheminova area on 11 November 1991, where gill mercury content was about $2850 \mathrm{ng} \mathrm{g}^{-1}$ dry wt (length $=38$ to $76 \mathrm{~mm}, \mathrm{n}=29$ ) (the term 'content' is used instead of 'concentration' since the latter relates amount of substance to solution, e.g. $\mu \mathrm{g}$ ALA per ml solution, whereas content relates one amount to another, e.g. $\mu$ g ALA per mg protein, or ng mercury per g tissue dry wt).

Ostrea edulis for aquaria experiments were sampled in the commercial oyster Crassostrea gigas (Thurnberg) tanks (ca $50 \times 25 \mathrm{~m}$ ) in Yerseke, Holland, on 20 September 1991 (length $=37$ to $93 \mathrm{~mm}, \mathrm{n}=75$ ) (Fig. 1). Blue mussels (length $=25$ to $40 \mathrm{~mm}, \mathrm{n}=50$ ), cockles (length $=16$ to $36 \mathrm{~mm}, \mathrm{n}=30$ ) and periwinkles (height $=11$ to $18 \mathrm{~mm}, \mathrm{n}=50$ ) for ALA analysis were sampled together with the oysters at Cheminova and at the shore at Skallingen and Yerseke (Fig. 1).

Mercury analyses. Mercury content was determined by cold vapour atomic absorption spectrometry (Beckmann Model 1248) as described by Sørensen \& 
Bjerregaard (1991) after the following preparation: $50 \mathrm{mg}$ of the tissue was moistened by addition of $0.2 \mathrm{ml}$ distilled water, and dissolved to clearness in $1 \mathrm{ml} 65 \%$ nitric acid at $55^{\circ} \mathrm{C}$ for $2 \mathrm{~h}$. After cooling to room temperature, $3 \mathrm{ml}(0.5,0.5,1.0$ and $1.0 \mathrm{ml}$ successively) $\mathrm{K}_{2} \mathrm{MnO}_{4}\left(60 \mathrm{~g} \mathrm{l}^{-1}\right)$ was added to the sample which was left in darkness for $30 \mathrm{~min}$ whereafter a $50 \% \mathrm{H}_{2} \mathrm{O}_{2}$ solution was added dropwise along the sides of the container to obtain a colorless, clear solution.

Biometry including physiological condition index. Shell length was measured (to nearest $0.1 \mathrm{~mm}$ ) as the longest distance between the ligament and the opposite shell edge. Dry weight of soft tissue was determined after freeze-drying and shell weight after drying at room temperature for at least $24 \mathrm{~h}$. The physiological condition index (Walne 1970) was calculated as dry weight of soft parts $\times 1000 /$ volume between shells (volume of intact animal less volume of shells). Scar length was measured as the longest distance of the muscle scar of the right (flat) shell, and width perpendicular to the length measurement (nearest $0.1 \mathrm{~mm}$ ).

Exposure experiments. Yerseke oysters were glued in natural position to removable plates with non-toxic aquarium glue. Half of the oysters were exposed to $100 \mathrm{ppb} \mathrm{Hg}$ administered as $\mathrm{HgCl}_{2}$ and the other half kept for reference. The oysters were fed continuously for 30 min twice a day with a suspension of Rhodomonas sp., and the continuously aerated water (35 l, $15^{\circ} \mathrm{C}$, salinity $=26 \mathrm{ppt}$ ) was renewed once a day. Samples $(n=4)$ were removed from the mercuryexposed aquaria and from the reference aquaria on Days $1,2,4,8,16$ and 32 .

ELISA detection of Bonamia ostreae. Individual samples of oyster hemolymph, $200 \mu$, were removed from the pericardium of freshly opened oysters, hemolyzed and stored at $-18^{\circ} \mathrm{C}$ for 1 to 2 mo. After thawing, the hemolymph was centrifuged $(3000 \times g$ for $5 \mathrm{~min}$ ) and the supernatant screened for antigens of the intracellular parasite Bonamia ostreae (Van Banning 1990) by an enzyme-linked immunosorbent assay (ELISA) using monoclonal-antibody-sensitized microtitration plates, and an alkaline phosphate conjugated monoclonal antibody (SONOFI AgroVeterinaire, Paris, France). Antigen material delivered from the above mentioned company was used for positive control following procedures recommended by the manufacturer.

Determination of $\delta$-aminolevulinic acid (ALA). Hepatopancreas from 4 to 5 individuals were dissected from thawing oysters, pooled and homogenized with half the amount of $100 \mathrm{mM}$ phosphate buffer, pH 6.8, and centrifuged $(3000 \times g$ for $10 \mathrm{~min})$. The supernatant was frozen at $-80^{\circ} \mathrm{C}$. All preparations were carried out on ice, and all procedures carried out without delays.
Prior to analysis thawed samples were ultrafuged $(80000 \times g)$. The determination of ALA concentration was based on the experimental procedure of Mauzerall \& Granick (1956) as described by Brock (1992).

The concentration of soluble protein in the hepatopancreatic homogenates was determined using the Bioret method (Gornall et al. 1949), and the relative ALA content was expressed in $\mu$ mol ALA $g^{-1}$ soluble protein. All determinations were replicated (variation $<5 \%$ ).

Statistics. Comparisons between exposed and nonexposed natural populations of Ostrea edulis were performed by discriminant analysis and by multivariate analysis of variance (MANOVA). Unlike univariate analysis of variance (ANOVA) which compares means of a single dependent variable, the MANOVA procedure compares sets of dependent variables which are correlated (Bartlett's test of sphericity). Multivariate differences were estimated from Pillai's trace. Violations of assumptions (multivariate normal distribution and equal covariance matrices for all groups) were assessed from univariate distributions (normal probability plots), homogeneity-of-variance tests (Cochran's $C$ and BartlettBox's F) for each variable individually, and from Box's M-test for multivariate homogeneity of the variance-covariance matrices.

In discriminant analysis, a linear combination of the independent variables serves as the basis for assigning cases to one group or another. Thus, information contained in multiple variables is summarized in a single index (discriminant score). In the linear discriminant equation $D=B_{0}+B_{1} X_{1}+B_{2} X_{2}+\ldots B_{n} X_{n}$, the $B$ 's are chosen so that the values of discriminant scores differ as much as possible between groups (i.e. $\mathrm{SS}_{\text {between-groups }}$ relative to $\mathrm{SS}_{\text {within-groups }}$ is a maximum). As is the case for the MANOVA procedure, a discriminant analysis assumes a multivariate normal distribution and equal covariance matrices for the 2 groups compared.

All analyses, including least-squares linear regression analysis used to compare exposed and nonexposed individuals in the laboratory experiments, were performed by SPSS software (SPSS, Inc., Chicago, IL, USA).

\section{RESULTS}

Determination of mercury content revealed high values (> $2000 \mathrm{ng} \mathrm{g}^{-1}$ dry wt) in the different tissue types of Ostrea edulis from the Cheminova area (Table 1) while oysters from the eastern part of the fjord contained less than $100 \mathrm{ng} \mathrm{g}^{-1}$ dry wt. Since hepatopancreatic tissue is relatively easy to identify and isolate, this tissue was chosen for the laboratory studies. 
Mercury content of hepatopancreatic tissue samples increased to very high levels (396 $\mu \mathrm{g} \mathrm{g}^{-1}$ dry $w \mathrm{t}$ ) during the exposure to high mercury-contaminated water concentrations in the laboratory (Fig. 2). These levels were 5 to 10 times higher than those recorded for field samples of the bivalve Mya arenaria (Fimreite et al. 1971). Since length correlates significantly $(\mathrm{p}<0.001)$ to scar length $(\mathrm{r}=0.56)$ and to scar width $(r=0.31)$, and since scar length and scar width are also correlated ( $\mathrm{r}=31$ ), the data, including these metric parameters, were analyzed by a MANOVA model. The highly significant within-cells correlations which justify the application of MANOVA were confirmed by Bartlett's test of sphericity $(p<0.0005)$, but even the sensitive multivariate test (Pillai's trace) failed to disclose effects due to mercury exposure $(F=1.20, \mathrm{p}>0.10)$. Box's $M$-test for multivariate homogeneity showed no effect due to mercury exposure $(p>0.01)$.

Univariate analysis of variation demonstrates insignificant differences between exposed $(n=29)$ and non-exposed oysters ( $n=69$ ) considering the characters length, physiological index, scar length or scar width (Table 2). Physiological index was correlated neither to length, scar length nor scar width $(r<0.18)$.

To achieve an impression of the level of character overlap for the 2 groups, discriminant analysis was used. Discriminant functions based on length, relative body mass, scar length and scar width revealed substantial overlap between contaminated and noncontaminated oysters, and, therefore, failed to separate

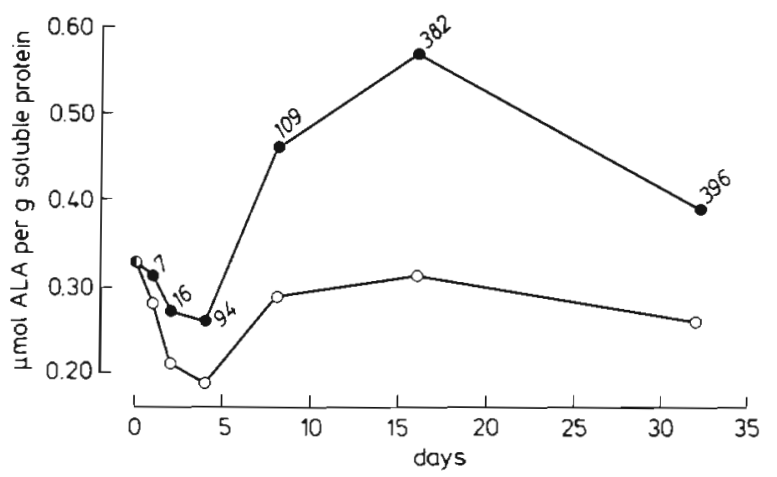

Fig. 2. Ostrea edulis. ALA content in oyster hepatopancreatic tissue (related to content of soluble protein) for bivalves exposed to $100 \mathrm{mg} \mathrm{Hgl}^{-1}$ (upper curve) and non-exposed (lower) oysters, in relation to days of exposure. Numbers along the upper curve give mercury concentration in $\mu \mathrm{g} \mathrm{g}^{-1} \mathrm{dry}$ wt; all the non-exposed samples contained less than $100 \mathrm{ng} \mathrm{g}^{-1}$ dry wt. Data points are based on duplicate analyses (range: less than $5 \%$ variation) of pooled material from 4 to 5 individuals the 2 groups. Based on this analysis, 26 of the 69 nonexposed individuals $(38 \%$ ), and 10 of the 29 exposed individuals $(35 \%)$ were misclassified. Discriminant function coefficients were: $B_{0}=-1.112 ; B_{1}$ (length) $=$ $-0.0768 ; B_{2}$ (physiological index) $=42.54 ; B_{3}$ (scar length $)=0.0981 ; B_{4}($ scar width $)=0.125$.

Assuming a linear relation between physiological condition index values and number of days exposed $(d)$, no changes in index values were found for the $\mathrm{Hg}$ exposed and the non-exposed oysters during $32 \mathrm{~d}$ of laboratory exposure experiments $(\mathrm{p}=0.77, \mathrm{p}=0.66$ respectively) [Index $\mathrm{H}_{\mathrm{Hg} \text {-exposed }}=-0.0016( \pm 0.0037) d+0.47$ $( \pm 0.057)_{i}$ Index $x_{\text {Non-exposed }}=0.0009( \pm 0.0031) d+0.42$ $( \pm 0.039)$ ]. Analysis of variance of physiological condition between exposed and non-exposed groups failed to reveal differences between these (Table 3).

The ELISA applied to detect possible infection by Bonamia ostreae revealed no traces of the parasite in any of the studied oysters. This finding was in accordance with tissue inspection which did not show the gill damage due to infection that occurs with severe attacks (Bucke \& Feist 1985).

ALA content (relative to protein) in environmental samples of Ostrea edulis, Mytilus edulis, Cerastoderma edule and Littorina littorina showed the same pattern of variation between polluted and control sites: environmentally mercury-exposed samples contained significantly higher amounts of ALA relative to protein than the corresponding non-exposed samples (Table 4).

The results of the laboratory exposure study showed elevated ALA content related to protein in all samples of mercury-exposed oysters as compared to corresponding

Table 3. Ostrea edulis. Physiological condition index of oysters. Comparisons of laboratory samples of mercuryexposed and non-exposed oysters were not significantly different. ANOVA, index by group

\begin{tabular}{lrrrrr} 
Source & $\begin{array}{c}\text { Sum of } \\
\text { squares }\end{array}$ & df & $\begin{array}{c}\text { Mean } \\
\text { square }\end{array}$ & $F$ & $p$ \\
\hline $\begin{array}{l}\text { Between groups } \\
\text { Within groups }\end{array}$ & 0.0059 & 1 & 0.0059 & 0.2218 & 0.64 \\
\hline
\end{tabular}


Table 4. Content of $\delta$-aminolevulinic acid (ALA) in relation to protein molluscs from mercury-contaminated (Cheminova) and uncontaminated (Yerseke or Wadden Sea) areas. The 35 to $74 \%$ increased ALA-values reflect metabolic disturbances due to environmental mercury contamination

\begin{tabular}{|lclcc|}
\hline Species & $\mathrm{n}$ & Location & $\begin{array}{c}\text { Sampling } \\
\text { period }\end{array}$ & $\begin{array}{c}\mu \text { mol ALA g } \\
\text { protein }\end{array}$ \\
\hline Ostrea edulis & 10 & Cheminova & Oct 1991 & 0.50 \\
O. edulis & 10 & Yerseke & Sep 1991 & 0.30 \\
Mytilus edulis & 50 & Cheminova & Oct 1991 & 0.70 \\
M. edulis & 50 & Yerseke & Sep 1991 & 0.52 \\
Littorina littorea & 50 & Cheminova & Oct 1991 & 0.80 \\
L. littorea & 50 & Yerseke & Sep 1991 & 0.46 \\
Cerastoderma edule & 30 & Cheminova & Sep 1991 & 1.79 \\
C. edule & 50 & Wadden Sea & Sep 1991 & 1.30 \\
\hline
\end{tabular}
(variation $<5 \%$ ) for hepatopancreatic tissue in Ostrea edulis and other

environmental study were matched by sampling time (matching physiological condition, gonad maturity, temperature), sampling area (matching values of salinity and food), and size (as an alternative to age determination which is difficult in oysters). Further, it was observed that no individuals was infected by the parasite Bonamia ostreae, therefore both infection stress and possible effects of mercury on viability of the parasite could be ignored.

The lack of Bonamia antigen may be ascribed to the age of the oysters. As mentioned, age determination is difficult in oysters which form irregular shells that consist of a loose shell matrix; as an alternative to age matching, shell size was used to non-exposed oysters at any sampling time during the laboratory experiment (Fig. 2). There was no simple relation between the $\mathrm{Hg}$-content in the tissue and the ALA content for the mercury-contaminated oysters. The initial drop and the drop after $32 \mathrm{~d}$ in ALA content for both groups suggest the influence of other stress factors.

\section{DISCUSSION}

Although according to Danish legislation only restricted amounts of chemicals from pesticide production can be released to the environment, there is no evidence that observed differences between the mercury-rich mollusc population and the reference population are not in fact an effect due to continuous release of low concentrations of such non-identified chemicals. In order to test whether some of the observed effects could be ascribed to mercury exposure, laboratory experiments were carried out. Since earlier studies of lead and cadmium levels in bivalves at the Cheminova site (Brock 1992) revealed low amounts of these trace metals, only mercury exposure was considered in this connection.

Inter-individual, within-population variation in content of a toxic substance and a corresponding biomarker is to be expected due simply to differences in reproductive stage, nutritional stages (Ruitz et al. 1992) and to some degree parasite infection (Van Banning 1990). These variables co-vary with sampling day. Inter-population variation of biomarkers is caused by environmental factors such as temperature, salinity (Denton \& Burdon-Jones 1981), food availability and sediment structure (Depledge \& Rainbow 1990). All these sources of 'natural' variability have to be accounted for when one matches populations in order to study possible effects of a toxin (Brock \& Brock 1993a). In order to take these sources of inter-population variation into account, the oyster groups in the match groups. The oyster samples from Nissum Bredning were all relatively small (length $<76 \mathrm{~mm}$ ) and therefore probably consisted mostly of males (direct sex-determination of the protandrous hermaphrodite was not carried out). According to Van Banning (1990), males are resistant to bonamiasis, and so the disease may possibly exist in older females in the area.

The results of the environmental study demonstrate that the actual level of mercury exposure at Cheminova does not stress these oysters to a degree which is reflected in their growth. Therefore, it is important to emphasize that environmental quality (and of course consumption safety) cannot be established by a demonstration of normal growth of Ostrea edulis, a species which otherwise is sensitive to habitat changes.

There is clearly no direct correspondence between the very high mercury tissue values recorded in the laboratory experiment and the ALA content. This is probably an effect of inactivation of bioavailable mercury by binding to metallothioneins. Roesijadi et al. (1989) characterized metallothioneins in the oyster Crassostrea virginica (Gmelin); similar substances may be responsible for inactivation of mercury ions, and the recorded very high bioaccumulation of mercury in Ostrea edulis.

The decline of ALA content towards the end of the experimental period in hepatopancreas in the mercury-exposed laboratory oysters may be caused by regulatory feed back mechanisms that counteract the initial response. In the field samples as well as in the laboratory experiments, however, ALA concentrations in matched groups were unambiguously found to be significantly higher in mercury-exposed than in non-exposed oysters. Inorganic mercury compounds readily react with the thiol groups of proteins and peptides (Bjerregaard \& Vislie 1985) and, thus, probably inhibit enzyme activity. Accordingly an obvious explanation of the observed enhancement of ALA content in mercury-exposed oysters is that this non-essential 


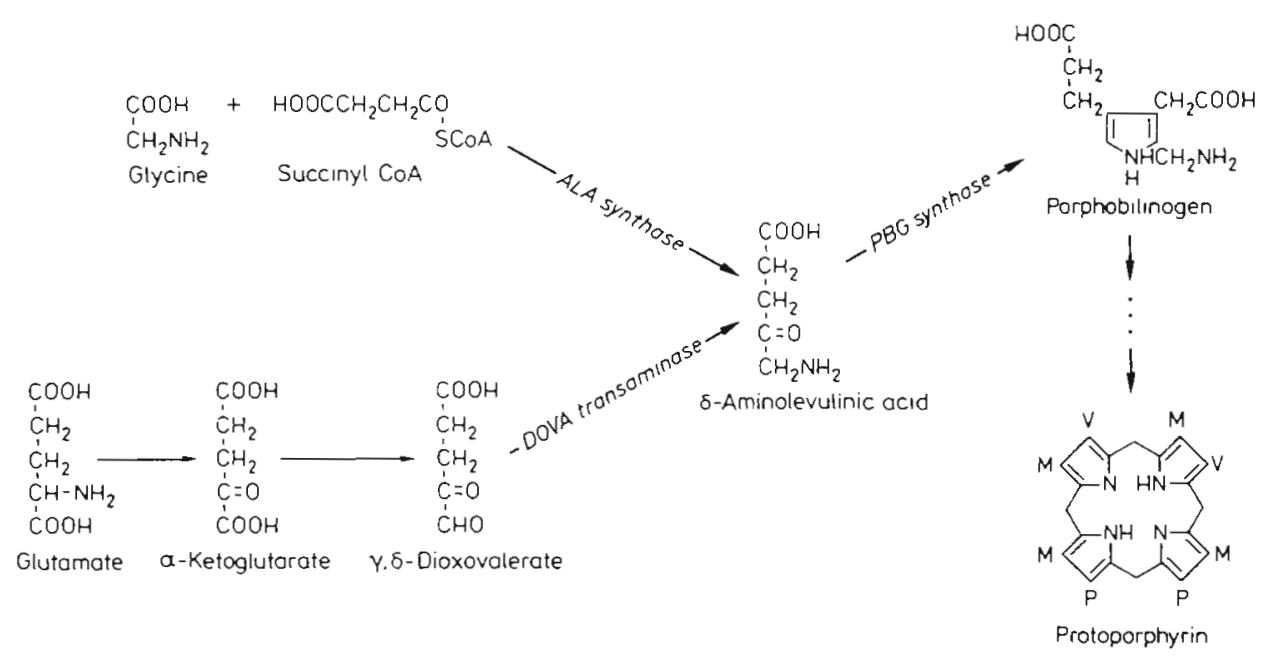

Fig. 3. Two possible pathways for $\delta$-aminolevulinic acid $(=5$ aminolevulinic acid, ALA) formation identified in the mitochondria of animal tissue (upper) and plant tissue (lower). Varticovski et al. (1980) have found indications of the 'glutamate' pathway in bovine hepatic tissue as well. According to present knowledge, the further condensation of $2 \mathrm{~mol}-$ ecules of ALA to porphobilinogen (PBG) is catalyzed by the enzyme ALA-D (= PBG synthase), and protoporphyrin is formed after 5 further specific reactions. For a suggested alternative pathway, see 'Discussion' metal inhibits ALA dehydratase (ALA-D) $=$ porphobilinogen synthase (PBG), in the same way as lead does in mammalian blood cells (Haeger-Aronson et al. 1971), a reaction which is considered specific for lead (Peakall 1992). For all eucaryote species, cytochromes are essential in organizing the electron flow of the mitochondrial electrontransport chain. One would therefore expect that a constant blocking of the biosynthesis rate of porphyrins (Fig. 3) would lead to severe reduction in the energy metabolism of the oysters. This is obviously not the case, neither for the long-term environmental exposure, nor for the shortterm, high-concentration laboratory exposure. Three possible explanations are suggested: (1) a reduced rate of cytochrome synthesis is still sufficient to satisfy the oysters' demands; (2) the oysters incorporate porphyrins from partly digested algae via the digestive tract; or (3) oyster porphyrin precursors are synthesized via an alternative, unknown pathway.

The elevated ALA content in field samples of mercury-exposed oysters, mussels, cockles and periwinkles reflects the occurrence of this xenobiotic. ALA is thus, according to the definition given above, a biomarker revealing sublethal toxic effects which do not in a detectable way affect the energy balance of the organism. Having established an as yet non-causal relationship between mercury contamination and ALA content, the next step (presently in progress) is to establish the causality of the observed effect. Studies of oyster ALA-D activity in native, 100 ppb mercury-, 100 ppb lead-, and 100 ppb cadmium-exposed groups have shown a lack of ALA-D in cockles (Brock \& Brock 1993b). This finding supports Explanation 3 above. Although mercury-contaminated oysters apparently thrive as well as non-exposed ones, the elevated content of the biomarker ALA clearly demonstrates metabolic disorder.
Acknowledgements. I am grateful to P. Bjerregaard and M. Depledge, Dept of Ecotoxicology at Odense University, Denmark, and to E. Bourget and E. Holm, Département de Biologie, Université Laval, Québec, Canada, for support and discussions. I especially thank A. Brock, Dept of Clinical Biochemistry, University of Aarhus, Denmark, for help and advice and appreciate the enthusiastic laboratory assistance of S. Boeriths, Odense University.

\section{LITERATURE CITED}

Bjerregaard, P., Vislie, T. (1985). Effects of mercury on ion and osmoregulation in the shore crab Carcinus maenas (L.). Comp. Biochem. Physiol. 82(C): $227-230$

Brock, A., Brock, V. (1993a). Factors affecting inter-individual variation in human plasma cholinesterase activity: body weight, height, sex, genetic polymorphism, and age. Arch. environ. Cont. Toxicol. 24: 93-99

Brock, V (1992). Effects of mercury on the biosynthesis of porphyrins in bivalve molluscs (Cerastoderma edule and C. Jamarcki). J. exp. mar. Biol. Ecol. 164: 17-29

Brock, V., Brock, A. (1993b). Increased 5-aminolevulinic acid (ALA) in heavy metal exposed bivalve molluscs, Cerastoderma edule: an effect due to inhibition of porphobilinogen synthase? Comp. Biochem. Physiol. (in press)

Bucke, D., Feist, S. (1985). Bonamiasis in the flat oyster, Ostrea edulis, with comments on histological techniques. In: Ellis, A. E. (ed.) Fish and shellfish pathology. Symposium proceedings. Academic Press, London, p. 287-392

Collin, J. (1872). Kort udsigt over Limfjordens Østersbanker. Tidsskrift for fiskeri $4: 1-22$

Denton, G. R. W., Burdon-Jones, C. (1981). Influence of temperature and salinity on the uptake, distribution and depuration of mercury, cadmium and lead by the black-lip oyster Saccostrea echinata. Mar. Biol 64: 317-326

Depledge, M. H., Rainbow, P. S. (1990). Models of regulation. and accumulation of trace metals in marine invertebrates. Comp. Biochem. Physiol. 97(C): 1-7

Elston, R. A., Kent, M. L., Wilkinson, M. T (1987). Resistance of Ostrea edulis to Bonamia ostreae infection. Aquaculture 64: $237-242$

Fimreite, N., Holsworth, W. N., Kelt, J. A., Pearce, P. A., Gruchy, I. M. (1971). Mercury in fish and fish-eating birds 
near sites of industrial contamination in Canada. Can. Fld Nat. 85: 211-220

Gornall, A. G., Bardawill, C. J., David, M. M. (1949). Determination of serum proteins by means of the Biuret reaction. J. biol. Chem. 177: 751-766

Haeger-Aronson, B., Abdulla, M., Fristed, B. (1971). Effect of lead on delta-aminolaevulinic acid dehydratase activity in red blood cells. Arch. environ. Health 23: 440-445

Johannesson, K., Rödström, E. M., Aase, H. (1989). Low genetic variability in Scandinavian populations of Ostrea edulis L. - possible causes and implications. J. exp. mar Biol. Ecol 128: $177-190$

National Research Council (1987). Committee on biological markers. Environ. Hith Perspect. 74: 3-9

Mauzerall, D., Granick, S. (1956). The occurrence and determination of $\delta$-aminolevulinic acid and porphobilinogen in urine. J. biol. Chem. 219: 435-446

Peakall, D. (1992). Animal biomarkers as pollution indicators. Chapman \& Hall, London, p. 1-290

Pichot, Y., Comps, M., Tigé, G., Grizel, H., Rabouin, A. M. (1980). Recherche sur Bonamia ostreae gen. n., sp. n., parasite nouveau de l'huitre plate Ostreae edulis L. Revue Trav. Inst. (Scient. tech.) Pêch. marit. 43: 131-140

Roesijadi, G., Kielland, S., Klerks, P. (1989). Purification and properties of novel molluscan metallothioneins. Arch.

This article was submitted to the editor
Biochem. Biophys. 273: 403-413

Ruitz, C., Matinez, M., Mosquera, G., Abad, M., Sánchez, J. L. (1992). Seasonal variation in condition, reproductive activity and biochemical composition of the flat oyster, Ostrea edulis, from San Cibran (Galıcia, Spain). Mar. Biol. 112: $67-74$

Sørensen, M., Bjerregaard, P. (1991). Interactive accumulation of mercury and selenium in the sea star Asterias rubens. Mar. Biol. 108: 269-276

Thaker, A. A., Haritos, A. A. (1989). Mercury bioaccumulation and effects on soluble peptides, proteins and enzymes in the hepatopancreas of the shrimp Callianassa tyrrhena. Comp. Biochem. Physiol. 94(C): 199-205

Van Banning, P. (1990). The life cycle of the oyster pathogen Bonamia ostreae with a presumptive phase in the ovarian tissue of the European flat oyster, Ostrea edulis. Aquaculture 84: 189-192

Varticovski, L., Kushner, J. P., Burnham, B. F. (1980). Biosynthesis of porphyrin precursors: purification and characterization of mammalian $\mathrm{L}$-alanine $\mathrm{X}$-X-dioxyvaleric acid aminotransferase. J. biol. Chem. 355: 3742

Walne, P. R. (1970). Seasonal variation of meat and glycogen content of seven populations of oysters Ostrea edulis L. and a review of the literature. Fish. Invest. Ser. II, Vol. XXVI, 3: 1-34

Manuscript first received: September 25, 1992

Revised version accepted: March 26, 1993 